\title{
Exendin-4 increases islet amyloid deposition but offsets the resultant beta cell toxicity in human islet amyloid polypeptide transgenic mouse islets
}

\author{
K. Aston-Mourney • R. L. Hull • S. Zraika • \\ J. Udayasankar • S. L. Subramanian • S. E. Kahn
}

Received: 14 January 2011 / Accepted: 17 March 2011 /Published online: 12 April 2011

(C) Springer-Verlag 2011

\begin{abstract}
Aims/hypothesis In type 2 diabetes, aggregation of islet amyloid polypeptide (IAPP) into amyloid is associated with beta cell loss. As IAPP is co-secreted with insulin, we hypothesised that IAPP secretion is necessary for amyloid formation and that treatments that increase insulin (and IAPP) secretion would thereby increase amyloid formation and toxicity. We also hypothesised that the unique properties of the glucagon-like peptide-1 (GLP-1) receptor agonist exendin-4 to maintain or increase beta cell mass would offset the amyloid-induced toxicity.

Methods Islets from amyloid-forming human IAPP transgenic and control non-transgenic mice were cultured for $48 \mathrm{~h}$ in $16.7 \mathrm{mmol} / \mathrm{l}$ glucose alone (control) or with exendin-4, potassium chloride $(\mathrm{KCl})$, diazoxide or somatostatin. Human IAPP and insulin release, amyloid deposition, beta cell area/ islet area, apoptosis and AKT phosphorylation levels were determined.

Results In control human IAPP transgenic islets, amyloid formation was associated with increased beta cell apoptosis and beta cell loss. Increasing human IAPP release with exendin-4 or $\mathrm{KCl}$ increased amyloid deposition. However, while $\mathrm{KCl}$ further increased beta cell apoptosis and beta cell loss, exendin-4 did not. Conversely, decreasing human IAPP release with diazoxide or somatostatin limited amyloid formation and its toxic effects. Treatment with exendin-4 was associated with an increase in AKT phosphorylation compared with control and $\mathrm{KCl}$-treated islets.
\end{abstract}

K. Aston-Mourney $(\bowtie) \cdot$ R. L. Hull $\cdot$ S. Zraika $\cdot$ J. Udayasankar

S. L. Subramanian $\cdot$ S. E. Kahn

Division of Metabolism, Endocrinology and Nutrition,

VA Puget Sound Health Care System (151),

1660 South Columbian Way,

Seattle, WA 98108, USA

e-mail: astonk@u.washington.edu
Conclusions/interpretation IAPP release is necessary for islet amyloid formation and its toxic effects. Thus, use of insulin secretagogues to treat type 2 diabetes may result in increased islet amyloidogenesis and beta cell death. However, the AKT-associated anti-apoptotic effects of GLP-1 receptor agonists such as exendin-4 may limit the toxic effects of increased islet amyloid.

Keywords Beta cell apoptosis - Beta cell area $\cdot$ Beta cell proliferation · Exendin-4 - GLP-1 receptor agonist - IAPP. Insulin secretion $\cdot$ Islet amyloid
Abbreviations
ER Endoplasmic reticulum
GLP-1 Glucagon-like peptide-1
IAPP Islet amyloid polypeptide
$\mathrm{KCl}$ Potassium chloride

\section{Introduction}

The islet beta cell lesion of type 2 diabetes is characterised by a failure to secrete sufficient insulin due to decreased beta cell mass and function [1]. Beta cell failure is progressive and manifests clinically as failure of monotherapy over time and the need for additional therapies to maintain glycaemic control [2]. Several factors underlie the progressive loss of beta cell mass and function in type 2 diabetes. One such factor is islet amyloid formation, which has been shown to be toxic to beta cells and contributes to beta cell loss [3-7].

The unique constituent of islet amyloid is islet amyloid polypeptide (IAPP), a normal product of the beta cell that is co-secreted with insulin [8]. Several studies have shown that increased production or secretion of IAPP per se is not 
sufficient for amyloid to form [9-11]. However, some evidence suggests that under pro-amyloidogenic conditions, the magnitude of IAPP secretion is an important determinant of islet amyloid formation. We have previously shown that glucose dose-dependently increases amyloid deposition in cultured islets with minimal amyloid forming at 5.5 and $11.1 \mathrm{mmol} / \mathrm{l}$ glucose, and increased amyloid forming at 16.7 and $33.3 \mathrm{mmol} / 1$ glucose [7]. This suggests that one factor contributing to amyloid formation may be an increase in beta cell secretory demand. In line with this, in human $I A P P$ transgenic mice under conditions that favour amyloid formation, reduction of beta cell secretory demand with insulin sensitisers resulted in decreased amyloid formation [12]. Additionally, increasing beta cell secretion with glucose, leucine, tolbutamide, $\alpha$-ketoisocaproic acid or glutamine has been shown to result in increased amyloid formation as measured by electron microscopy in cultured transgenic mouse islets [13]. As the formation of amyloid is toxic to the beta cell and is associated with beta cell loss [3-7], it is of interest and perhaps even imperative to determine whether insulin secretagogues exacerbate beta cell loss via their effect of increasing amyloid formation.

A class of medications recently introduced for treatment of type 2 diabetes is the glucagon-like peptide-1 (GLP-1) receptor agonists [14]. These compounds have been shown to increase insulin secretion in a glucose-dependent manner, and in clinical trials have been found to lower $\mathrm{HbA}_{1 \mathrm{c}}$ levels and induce weight loss [15-17]. It has also been suggested, on the basis of in vitro studies with human islets, that GLP-1 receptor agonists are capable of preserving islet morphology [18], while in vitro and in vivo studies examining rodent islets suggest that GLP-1 receptor agonists may preserve or even increase beta cell mass [19-22]. Thus, it is possible that GLP-1 receptor agonists may have long-term beneficial effects on the beta cell. Evidence that GLP-1 receptor agonists protect against amyloid-induced toxicity comes from a recent study where the GLP-1 receptor agonist exendin-4 was able to partially protect immortalised beta cells from apoptosis and growth inhibition induced by acute treatment with exogenously applied, supraphysiological concentrations of synthetic IAPP [23]. However, it is not known whether this protection occurs under conditions where amyloid forms from endogenously released IAPP.

While aggregation of IAPP is well established as being toxic to beta cells, the site of formation and toxicity of IAPP aggregates has been under much debate. Studies suggest that extracellular and intracellular deposits can exert beta cell toxicity (reviewed by Khemtemourian et al. and Haataja et al. [24, 25]). Thus, determining whether secretion of IAPP is necessary for amyloid formation and beta cell toxicity will also determine whether intracellular and/or extracellular IAPP aggregates are the species that cause beta cell toxicity.
A major difference between human and rodent islets is the propensity of human islets to form islet amyloid [26]. However, as studies examining pancreatic morphology in humans are inherently limited, the use of animal models is essential. Since mouse IAPP is not amyloidogenic, we developed a transgenic mouse model that expresses human $I A P P$ in its beta cells and develops amyloid deposits morphologically indistinguishable from those in humans [27]. Amyloid formation in these mice is associated with beta cell loss and secretory dysfunction in vivo $[4,28]$ and beta cell apoptosis and oxidative stress in vitro [6]. Thus this mouse model mimics many features of the human islet lesion, making it particularly suited to study of the effects of medications on islet amyloid formation and its consequences. Moreover, the non-amyloid-forming nontransgenic islets provide the ideal control for the effects of the interventions independently of islet amyloid, something that cannot be done in studies using human islets.

We therefore used islets isolated from our human IAPP transgenic mice along with non-transgenic control islets to determine whether human IAPP secretion is a determinant of amyloid deposition and its toxic effects. We also determined whether anti-apoptotic and pro-proliferative effects of GLP-1 receptor agonists occur in the setting of amyloidogenesis, and whether they can offset the toxicity of islet amyloid formation and provide added benefit to the beta cell.

\section{Methods}

Islet isolation and culture Islets were isolated from 10-weekold hemizygous F1 C57BL/6 $\times \mathrm{DBA} / 2 \mathrm{~J}$ human IAPP transgenic mice and their non-transgenic littermates, as previously described [7]. 'Principles of laboratory animal care' (NIH publication no. 85-23, revised 1985; http:// grants1.nih.gov/grants/olaw/references/phspol.htm) were followed. Animal studies were approved by the Institutional Animal Care and Use Committee at the VA Puget Sound Health Care System.

Islets were cultured overnight in RPMI-1640 medium containing $10 \%$ (wt/vol.) fetal bovine serum, $100 \mathrm{U} / \mathrm{ml}$ penicillin, $100 \mu \mathrm{g} / \mathrm{ml}$ streptomycin and $11.1 \mathrm{mmol} / \mathrm{l} \mathrm{glu}-$ cose, and then cultured for $48 \mathrm{~h}$ (or $144 \mathrm{~h}$ in a subset of studies) in medium containing $16.7 \mathrm{mmol} / \mathrm{l}$ glucose with and without exendin-4 (American Peptide Company, Sunnyvale, CA, USA) or the secretion inhibitors diazoxide (Sigma-Aldrich, St Louis, MO, USA) or somatostatin (Sigma-Aldrich). Concentration-response studies were performed (data not shown) and final concentrations chosen so that exendin-4 (10 nmol/l) maximally stimulated, while diazoxide $(250 \mu \mathrm{mol} / \mathrm{l})$ and somatostatin $(100 \mathrm{nmol} / \mathrm{l})$ maximally inhibited insulin release. We chose $16.7 \mathrm{mmol} / \mathrm{l}$ glucose for two reasons. First, we have previously shown this is 
a pro-amyloidogenic condition that allows modulation of amyloid formation [7]. Second, exendin-4 increases insulin release in a glucose-dependent manner; thus, this is an appropriate glucose concentration at which to determine the consequences of exendin- 4 action.

To establish a secretagogue control that would match insulin output achieved by exendin- 4 without beneficial effects on beta cell apoptosis and/or replication, the sulfonylureas glibenclamide (Sigma-Aldrich) and tolbutamide (SigmaAldrich), as well as potassium chloride ( $\mathrm{KCl}$ ) (Sigma-Aldrich) were tested (concentration-response data not shown). Glibenclamide $(0.5 \mu \mathrm{mol} / \mathrm{l})$ and tolbutamide $(0.5 \mathrm{mmol} / \mathrm{l})$ did not increase insulin release throughout the $48 \mathrm{~h}$ culture period (31.1 glibenclamide vs $32.0 \mathrm{nmol}^{-1}$ islet $^{-1}$ control, $p=0.99$, $n=4 ; 31.7$ tolbutamide vs $31.2 \mathrm{nmol} \mathrm{l}^{-1}$ islet $^{-1}$ control, $p=0.89, n=4)$, consistent with many studies showing a decreased effect of continued sulfonylurea treatment on insulin release $[29,30]$. In contrast, $\mathrm{KCl}(10 \mathrm{mmol} / \mathrm{l})$ was effective in increasing insulin release $(37.8 \mathrm{KCl}$ vs $22.3 \mu \mathrm{mol} \mathrm{l}^{-1}$ islet $^{-1}$ control, $p=0.01, n=8$ ). Thus, a second set of experiments was performed culturing islets with and without $\mathrm{KCl}$.

To determine the effects of increasing insulin release under physiological glucose concentration, islets were also cultured in media containing $11.1 \mathrm{mmol} / \mathrm{l}$ glucose with and without exendin-4 $(10 \mathrm{nmol} / \mathrm{l})$ and $\mathrm{KCl}(10 \mathrm{mmol} / \mathrm{l})$.

Determination of optimal study length We have previously shown that amyloid is detectable as early as $24 \mathrm{~h}$ after culture in $16.7 \mathrm{mmol} / \mathrm{l}$ glucose, its deposition increasing progressively over $144 \mathrm{~h} \mathrm{[7]}$. To determine the optimal culture time for the current study, islets were cultured for $144 \mathrm{~h}$ with or without exendin- 4 with samples taken at $48 \mathrm{~h}$ intervals. In the first $48 \mathrm{~h}$, exendin- 4 significantly increased insulin release $\left(46.5 \pm 1.5\right.$ exendin- 4 vs $33.5 \pm 1.6 \mathrm{nmol} \mathrm{l}^{-1}$ islet $^{-1}$ control, $p=0.007, n=4)$. However, following this period exendin- 4 no longer increased insulin release above control (48-96 h, 23.6 \pm 3.2 exendin-4 vs $28.7 \pm 3.6 \mathrm{nmol}^{-1}$ islet $^{-1}$ control, $p=0.02$; $96-144 \mathrm{~h}, 20.8 \pm 0.9$ exendin- 4 vs $23.6 \pm$ $1.8 \mathrm{nmol} \mathrm{l}^{-1}$ islet $^{-1}$ control, $p=0.19$ ), consistent with the documented effect that prolonged exendin-4 treatment results in GLP-1 receptor desensitisation in vitro [31]. Therefore, we determined that culture for $48 \mathrm{~h}$ provided the best time period for assessing the effects of exendin-4.

Assessment of human IAPP, and insulin release and content For measurement of hormone release, five islets were cultured in $1 \mathrm{ml}$ of medium in triplicate for $48 \mathrm{~h}$ as previously described [13] and the concentrations of human IAPP and insulin in the culture medium measured. For content, five islets in triplicate were extracted with acidethanol [6]. Human IAPP and insulin concentrations were determined by ELISA (Human Amylin Immunoabsorbance
Assay, with F024 and F002 as the capture and detection antibodies respectively, a gift from Amylin Pharmaceuticals, San Diego, CA, USA; and Insulin Ultrasensitive [Mouse] ELISA from Alpco, Salem, NH, USA).

Histological measurement of amyloid deposition, beta cell area, beta cell apoptosis and beta cell proliferation Islets were fixed in $4 \%$ (wt/vol.) phosphate-buffered paraformaldehyde for $30 \mathrm{~min}$ and embedded in agar and then in paraffin [7]. Sections $(10 \mu \mathrm{m})$ were labelled as described below and assessments made by an observer blinded to the status of the sample on an average of 20 islets per condition per experiment using Image Pro Plus (Media Cybernetics, Bethesda, MD, USA). For assessment of amyloid and beta cell area/islet area, sections were labelled with thioflavin $\mathrm{S}$ to visualise amyloid deposits, insulin antibody to visualise beta cells and Hoechst 33258 to visualise nuclei; amyloid and insulin area were expressed as a percentage of total islet area. For quantification of apoptosis and proliferation, the number of apoptotic and proliferating beta cells were determined by manual counting of apoptotic nuclei (using propidium iodide labelling to identify condensed nuclei) and Ki67-positive nuclei respectively in insulin-positive cells and expressed as a percentage of total cell number.

$R N A$ isolation and quantitative real-time PCR Total RNA was isolated from 25 islets per condition (High Pure RNA isolation kit; Roche Applied Science, Indianapolis, IN, USA) and reverse-transcribed (High Capacity cDNA Archive kit; Applied Biosystems, Foster City, CA, USA). mRNA expression of human IAPP and Insulin II gene was measured in triplicate using the TaqMan system (ABI Prism 7000; Applied Biosystems) with assays on demand (human IAPP, Hs00169095_m1; Insulin II, Mm00731595_gH; Applied Biosystems) and $18 \mathrm{~S}$ as the endogenous control (Hs99999901_s1, Applied Biosystems). mRNA levels were calculated using the $2^{-\Delta \mathrm{C}_{\mathrm{t}}}$ method and expressed relative to the experimental control (human IAPP transgenic no drug control for human $I A P P$ and non-transgenic no drug control for insulin).

Phosphorylated AKT and AKT western blotting Total protein was extracted from at least 200 islets per condition (Cell Lysis kit; Bio-Rad Laboratories, Hercules, CA). Islet protein ( $35 \mu \mathrm{g}$ islet protein per sample) was separated by SDS-PAGE, transferred to PVDF membrane and then probed with a pAKT antibody (1:500; Cell Signaling, Danvers, MA, USA) or total AKT antibody (1:500; Cell Signaling), followed by a goat anti-rabbit immunoglobulin/ horseradish peroxidase antibody (1:50,000; Dako, Carpinteria, CA, USA). Protein levels were normalised to the nontransgenic no drug control and pAKT expressed as a proportion of total AKT. 
Statistical analyses Data are expressed as mean \pm SEM and were compared by analysis of variance with least significant difference post-hoc analysis, or by Kruskal-Wallis and Mann-Whitney $U$ non-parametric tests if not normally distributed. A value of $p<0.05$ was considered statistically significant.

\section{Results}

Human IAPP, and insulin release and content When human IAPP transgenic islets were cultured for $48 \mathrm{~h}$ in $16.7 \mathrm{mmol} / \mathrm{l}$ glucose with exendin-4 or $\mathrm{KCl}$, human IAPP release was increased compared with human IAPP transgenic islets in $16.7 \mathrm{mmol} / \mathrm{l}$ glucose alone (Fig. 1a, b). The magnitude of increased human IAPP release was similar with exendin-4 and $\mathrm{KCl}$. Conversely, culture with diazoxide or somatostatin decreased human IAPP release (Fig. 1a, c). Insulin release was also increased by exendin- 4 and $\mathrm{KCl}$, and decreased by diazoxide and somatostatin and did not differ between human IAPP transgenic and non-transgenic islets for any treatment (Fig. 1d-f).

When human IAPP transgenic islets were cultured in the presence of exendin- 4 or $\mathrm{KCl}$, human IAPP content was significantly lower than in human IAPP transgenic control islets (Tables 1 and 2). Conversely, in the presence of diazoxide, human IAPP content was significantly increased (Table 1). Similarly, insulin content was decreased by exendin- 4 and $\mathrm{KCl}$, and increased by diazoxide and did not differ between human IAPP transgenic and non-transgenic islets for any given treatment (Tables 1 and 2).

Human IAPP and insulin mRNA levels To determine whether the selected treatments affected human IAPP or insulin mRNA expression, real-time PCR was performed. Islets cultured in $16.7 \mathrm{mmol} / \mathrm{l}$ glucose for $48 \mathrm{~h}$ revealed no difference in mRNA levels of human IAPP or insulin under any treatment (Tables 1 and 2).

Islet amyloid deposition Culture of human IAPP transgenic islets for $48 \mathrm{~h}$ in $16.7 \mathrm{mmol} / 1$ glucose was associated with extracellular islet amyloid deposition, while, as expected, no amyloid was present in non-transgenic islets (Fig. 2a-d). Culture with either exendin- 4 or $\mathrm{KCl}$ resulted in a similar increase in amyloid deposition relative to human IAPP transgenic control islets (1.9-fold exendin-4 vs 1.7-fold $\mathrm{KCl}, p=0.25$; Fig. 2a-c). In contrast, diazoxide and somatostatin decreased amyloid deposition relative to control human IAPP transgenic islets (Fig. 2a, b, d).

Beta cell apoptosis Amyloid formation in human IAPP transgenic control islets was associated with an increase in beta cell apoptosis compared with non-transgenic control a
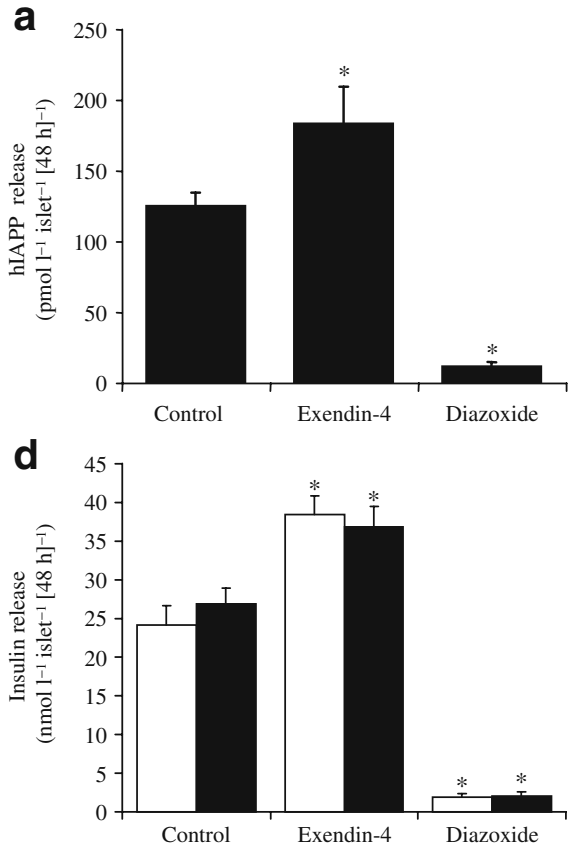

b

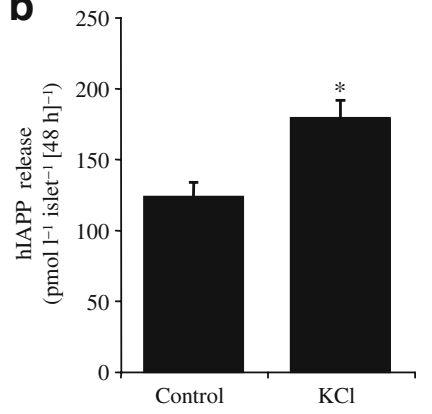

e

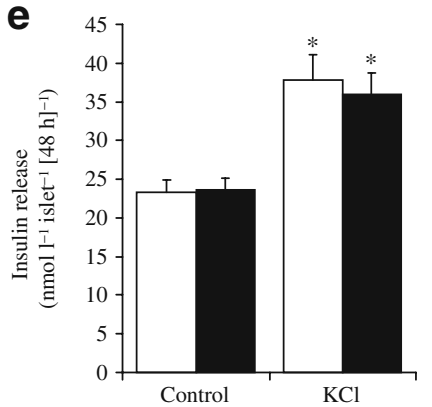

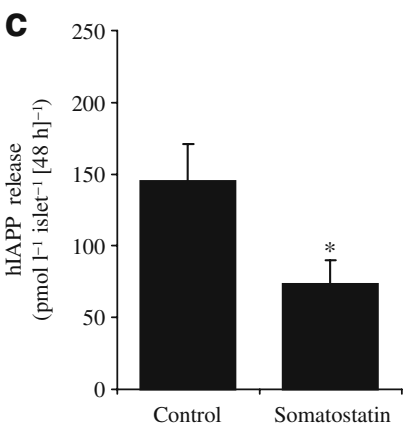

f

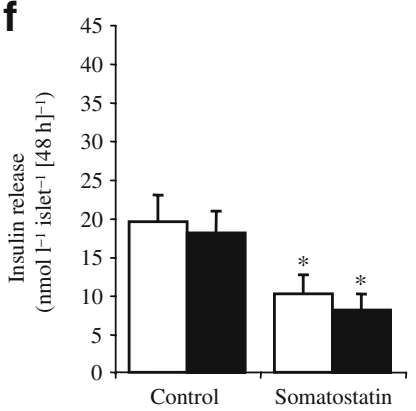

Fig. 1 a-c Human IAPP (hIAPP) release (pmol l-1 islet $^{-1}[48 \mathrm{~h}]^{-1}$ ) from human IAPP transgenic islets cultured for $48 \mathrm{~h}$ in $16.7 \mathrm{mmol} /$ 1 glucose with treatments as labelled. $\mathbf{d}-\mathbf{f}$ Insulin release $\left(\mathrm{nmol}{ }^{-1}\right.$ islet ${ }^{-1}[48 \mathrm{~h}]^{-1}$ ) from non-transgenic (white bars) and human IAPP transgenic (black bars) islets cultured in $16.7 \mathrm{mmol} / \mathrm{l}$ glucose with treatments as labelled. Treatments: no drug (control), exendin-4 $(10 \mathrm{nmol} / \mathrm{l})$, diazoxide $(250 \mu \mathrm{mol} / \mathrm{l}), \mathrm{KCl}(10 \mathrm{mmol} / \mathrm{l})$, somatostatin $(100 \mathrm{nmol} / \mathrm{l})$. Values are mean $\pm \mathrm{SEM} ; n=6-9 ; * p<0.05 \mathrm{vs}$ control 
Table 1 Content and mRNA levels of human IAPP and insulin with exendin-4 and diazoxide treatment

\begin{tabular}{|c|c|c|c|c|c|c|}
\hline & \multicolumn{3}{|c|}{ Non-transgenic } & \multicolumn{3}{|c|}{ Human $I A P P$ transgenic } \\
\hline & Control & Exendin-4 & Diazoxide & Control & Exendin-4 & Diazoxide \\
\hline Human IAPP content $\left(\mathrm{pmol} \mathrm{l}^{-1}\right.$ islet $\left.^{-1}\right)$ & - & - & - & $64.7 \pm 8.1$ & $34.3 \pm 4.3^{*}$ & $131.6 \pm 19.0^{*}$ \\
\hline Insulin content (nmol $1^{-1}$ islet $^{-1}$ ) & $12.4 \pm 3.7$ & $5.1 \pm 1.3^{*}$ & $27.5 \pm 6.7^{*}$ & $10.2 \pm 1.7$ & $5.8 \pm 1.5^{*}$ & $22.7 \pm 5.1^{*}$ \\
\hline Human IAPP mRNA & - & - & - & $1.00 \pm 0.28$ & $0.93 \pm 0.37$ & $0.91 \pm 0.34$ \\
\hline Insulin mRNA & $1.00 \pm 0.17$ & $1.13 \pm 0.12$ & $0.79 \pm 0.08$ & $1.11 \pm 0.18$ & $1.32 \pm 0.19$ & $0.84 \pm 0.12$ \\
\hline
\end{tabular}

Values are mean $\pm \mathrm{SEM}$

$* p<0.05$ vs control

islets (Fig. 3b-d). Human IAPP transgenic islets treated with exendin-4 exhibited increased beta cell apoptosis compared with non-transgenic islets treated with exendin-4 (Fig. 3b). However, despite increased amyloid formation, beta cell apoptosis was not significantly different from human IAPP transgenic control islets (0.8-fold, $p=0.35$; Fig. 3b). In contrast, the increase in amyloid observed in human IAPP transgenic islets with $\mathrm{KCl}$ was associated with a 2.1-fold increase in beta cell apoptosis when compared with human IAPP transgenic control islets (Fig. 3c). Despite similar increases in amyloid deposition, based on fold differences over controls, beta cell apoptosis in human IAPP transgenic islets treated with exendin- 4 was reduced compared with $\mathrm{KCl}$ treated islets $(p=0.007)$. The increased apoptosis with $\mathrm{KCl}$ was not due to a toxic effect of $\mathrm{KCl}$ treatment as such, as there was no difference in rates of beta cell apoptosis in non-transgenic islets cultured with or without $\mathrm{KCl}(p=0.7)$. When amyloid formation was decreased with diazoxide or somatostatin, beta cell apoptosis decreased compared with human IAPP transgenic control islets and was comparable to similarly treated non-transgenic islets (Fig. 3b, d).

Beta cell proliferation No changes in beta cell proliferation were detectable between non-transgenic and human IAPP transgenic islets or under any treatment condition (Fig. 4b, c).

Beta cell area/islet area Islet area did not differ among any treatment group (average islet area 10,757 $\pm 356 \mu \mathrm{m}^{2}$, $p=0.53)$. Thus, any changes in beta cell area did not result from alterations in islet size.

Table 2 Content and mRNA levels of human IAPP and insulin with $\mathrm{KCl}$ treatment

Values are mean \pm SEM

${ }^{*} p<0.05$ vs control
Amyloid formation together with increased beta cell apoptosis in human IAPP transgenic control islets was associated with a significant reduction in beta cell area/islet area when compared with non-transgenic control islets (Fig. 5a-c). In contrast, despite increased amyloid formation in human IAPP transgenic islets treated with exendin-4, beta cell area/islet area was not significantly different between human IAPP transgenic islets with or without exendin-4 treatment, or between human IAPP transgenic and nontransgenic islets treated with exendin-4 (Fig. 5a). On the other hand, human IAPP transgenic islets treated with $\mathrm{KCl}$ exhibited a marked reduction in beta cell area/islet area compared with control human IAPP transgenic islets and non-transgenic KCl-treated islets, consistent with the observed increase in beta cell apoptosis (Fig. 5b). The decreased beta cell area/islet area in $\mathrm{KCl}$-treated human $I A P P$ transgenic islets was not due to an effect of $\mathrm{KCl}$ treatment as such, as non-transgenic islets with and without $\mathrm{KCl}$ treatment had similar beta cell area/islet area $(p=0.6)$. Human IAPP transgenic islets treated with diazoxide or somatostatin exhibited increased beta cell area/islet area compared with human IAPP transgenic control islets, such that beta cell area/islet area did not differ between similarly treated human IAPP transgenic and non-transgenic islets (Fig. 5a, c).

Effect of increased beta cell secretion on amyloid formation at physiological glucose In islets cultured in $11.1 \mathrm{mmol} / 1$ glucose for $48 \mathrm{~h}$, exendin- 4 and $\mathrm{KCl}$ treatment resulted in increased insulin release (Fig. 6a).

\begin{tabular}{|c|c|c|c|c|}
\hline & \multicolumn{2}{|c|}{ Non-transgenic } & \multicolumn{2}{|c|}{ Human $I A P P$ transgenic } \\
\hline & Control & $\mathrm{KCl}$ & Control & $\mathrm{KCl}$ \\
\hline Human IAPP content (pmol l-1 islet $^{-1}$ ) & - & - & $78.7 \pm 16.8$ & $36.5 \pm 6.9^{*}$ \\
\hline Insulin content $\left(\mathrm{nmol} \mathrm{l}^{-1}\right.$ islet $^{-1}$ ) & $9.2 \pm 2.7$ & $5.9 \pm 1.8^{*}$ & $9.2 \pm 2.0$ & $5.0 \pm 1.2^{*}$ \\
\hline Human $I A P P$ mRNA & - & - & $1.00 \pm 0.19$ & $1.07 \pm 0.20$ \\
\hline Insulin mRNA & $1.00 \pm 0.21$ & $0.92 \pm 0.20$ & $0.99 \pm 0.13$ & $1.01 \pm 0.12$ \\
\hline
\end{tabular}




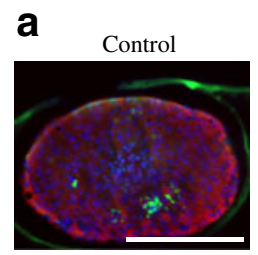

b

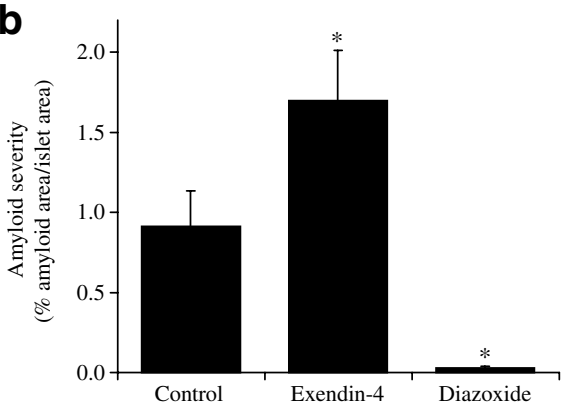

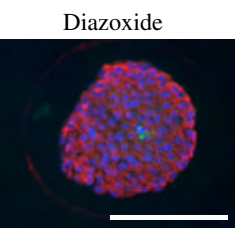

C

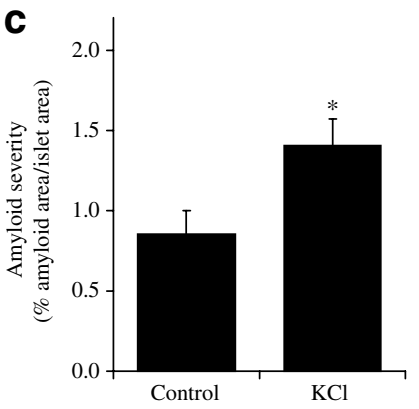

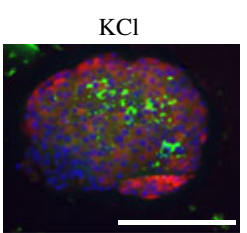

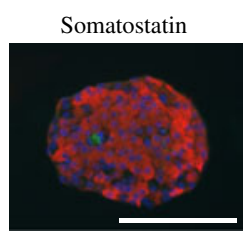

d

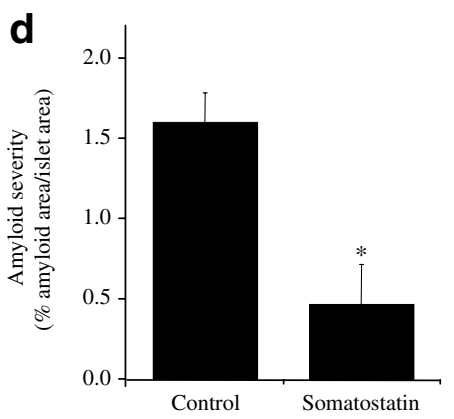

Fig. 2 a Representative images of human IAPP transgenic islets cultured for $48 \mathrm{~h}$ in $16.7 \mathrm{mmol} / 1$ glucose with treatments as indicated. Green, amyloid; red, insulin; blue, nuclei. Scale bar $100 \mu \mathrm{m}$. b-d Islet amyloid severity (\% amyloid area/islet area) in human IAPP transgenic islets cultured for $48 \mathrm{~h}$ in $16.7 \mathrm{mmol} / 1$ glucose with

As expected, culture of human IAPP transgenic islets for $48 \mathrm{~h}$ in $11.1 \mathrm{mmol} / \mathrm{l}$ glucose was associated with minimal islet amyloid formation, while no amyloid was present in non-transgenic islets (Fig. 6b). This minimal amyloid formation was not associated with any changes in beta cell apoptosis or beta cell area/islet area compared with nontransgenic islets (Fig. 6c, d). Culture with exendin-4 and $\mathrm{KCl}$ resulted in a significant increase in amyloid deposition relative to human IAPP transgenic control islets (Fig. 6b). Again however, this small increase in amyloid was not associated with a change in beta cell apoptosis or beta cell area/islet area (Fig. 6c, d).

Activation of AKT as a molecular mechanism for the protective effect of exendin-4 Finally, we sought to eluci- treatments as labelled. Non-transgenic islets did not form amyloid. Treatments: no drug (control), exendin-4 (10 nmol/l), diazoxide $(250 \mu \mathrm{mol} / \mathrm{l}), \mathrm{KCl}(10 \mathrm{mmol} / \mathrm{l})$, somatostatin $(100 \mathrm{nmol} / \mathrm{l})$. Values are mean \pm SEM; $n=6-9 ; * p<0.05$ vs control

date the molecular mechanism that may explain the ability of exendin-4 to limit beta cell apoptosis in the face of amyloid formation. Amyloid formation in human IAPP transgenic islets was not associated with decreased AKT phosphorylation when compared with non-transgenic islets (Fig. 7). However, exendin-4 treatment was associated with a 1.5-fold increase in phosphorylation of AKT in human IAPP transgenic and non-transgenic islets (Fig. 7).

\section{Discussion}

We have demonstrated that in human IAPP transgenic mouse islets cultured under amyloidogenic conditions induced by high glucose decreased human IAPP release a

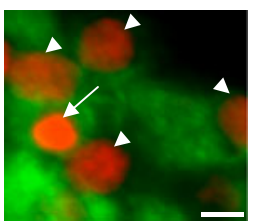

b

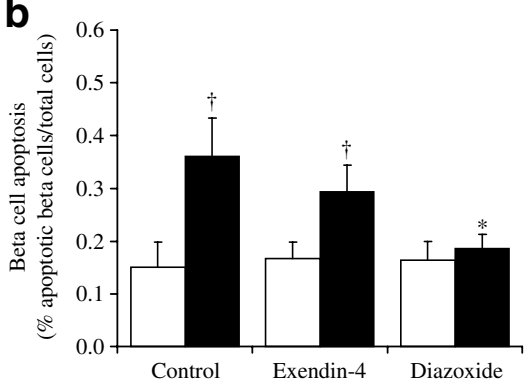

Fig. 3 a Representative image of propidium iodide staining indicating an apoptotic nucleus (arrow) and non-apoptotic nuclei (arrowheads). Red, propidium iodide; green, insulin. Scale bar $10 \mu \mathrm{m}$. b-d Beta cell apoptosis (\% apoptotic beta cells/total cells) in non-transgenic (white bars) and human IAPP transgenic (black bars) islets cultured for $48 \mathrm{~h}$
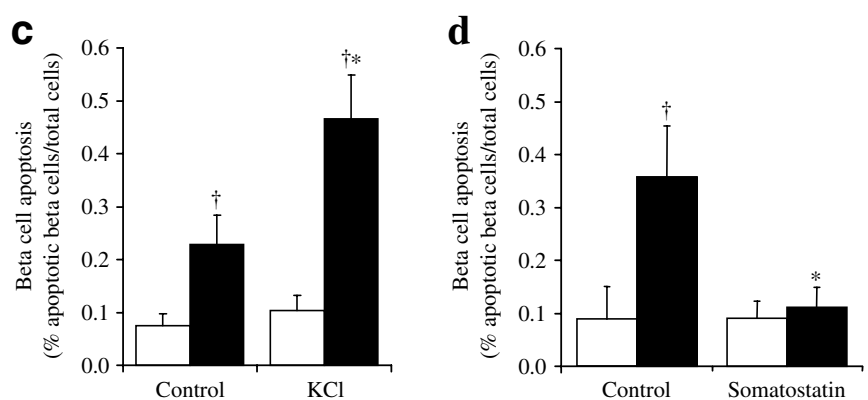

in $16.7 \mathrm{mmol} / 1$ glucose with treatments as labelled. Treatments: no drug (control), exendin-4 (10 nmol/l), diazoxide $(250 \mu \mathrm{mol} / \mathrm{l}), \mathrm{KCl}$ $(10 \mathrm{mmol} / \mathrm{l})$, somatostatin $(100 \mathrm{nmol} / \mathrm{l})$. Values are mean $\pm \mathrm{SEM} ; n=6-9$; $* p<0.05$ vs control, ${ }^{\dagger} p<0.05$ vs non-transgenic 

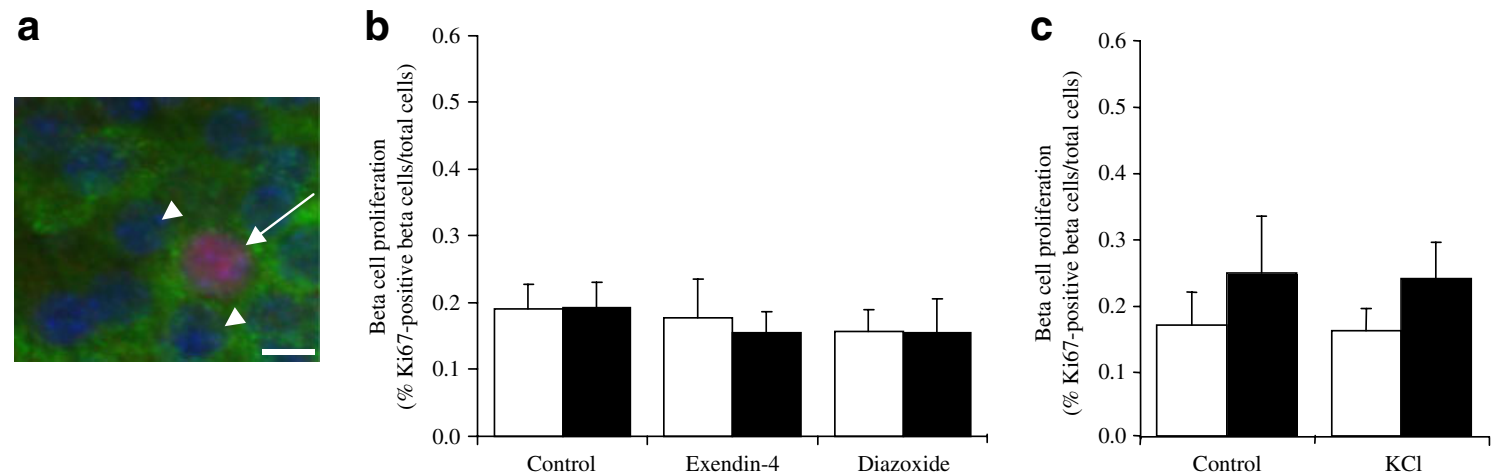

Fig. 4 a Representative image of Ki67 staining indicating a proliferating nucleus (arrow) and non-proliferating nuclei (arrowheads). Red, Ki67; green, insulin; blue, nuclei. Scale bar $10 \mu \mathrm{m}$. b-c Beta cell proliferation ( $\%$ Ki67 positive beta cells/total cells) in non- transgenic (white bars) and human IAPP transgenic (black bars) islets cultured for $48 \mathrm{~h}$ in $16.7 \mathrm{mmol} / 1$ glucose with treatments as labelled. Treatments: no drug (control), exendin-4 (10 nmol/1), diazoxide $(250 \mu \mathrm{mol} / \mathrm{l}), \mathrm{KCl}(10 \mathrm{mmol} / \mathrm{l})$. Values are mean $\pm \mathrm{SEM} ; n=6-9$ with diazoxide or somatostatin treatment resulted in decreased amyloid deposition and beta cell apoptosis, and in preservation of beta cell area/islet area to levels similar to those in non-transgenic islets. This indicates that human IAPP release from the beta cell is critical for amyloid formation. Further, as diazoxide treatment also resulted in increased cellular content of human IAPP, the intracellular accumulation of human IAPP is not sufficient to result in amyloid formation or induce beta cell apoptosis. This supports the concept that extracellular aggregation of human IAPP is toxic and can result in beta cell loss.

Under these same amyloidogenic conditions, treatment with the GLP-1 receptor agonist exendin-4 further increased amyloid deposition. However, beta cell apoptosis was lower and beta cell area/islet area was higher than would be expected for this increased level of amyloid formation. Therefore, while exendin-4 results in increased amyloidogenesis, it also appears to offset the toxic effects of amyloid deposition by limiting beta cell apoptosis, resulting in beta cell preservation. Consistent with this hypothesis, increased human IAPP release with $\mathrm{KCl}$, which was not expected to exert anti-apoptotic effects, resulted in a similar increase in amyloid deposition as with exendin-4, but simultaneously also increased beta cell apoptosis, the net result being a decrease in beta cell area/islet area. These results are also consistent with the effects of exendin- 4 and $\mathrm{KCl}$ in increasing amyloid deposition at lower $(11.1 \mathrm{mmol} / \mathrm{l})$ glucose. However, with this glucose concentration, only minimal amounts of amyloid formed, resulting in no detectible increase in beta cell apoptosis or beta cell loss.

GLP-1 receptor agonists have been shown to enhance beta cell survival by decreasing apoptosis in many contexts, including islet transplantation [32]. In vitro experiments have shown that GLP-1 receptor agonists protect the beta cell from apoptosis resulting from insults, including those from cytokines, endoplasmic reticulum (ER) stress and glucolipotoxicity, as previously reviewed [33]. A major signalling molecule induced by GLP-1 receptor agonists is protein kinase $\mathrm{A}$, which in turn activates the protein kinase AKT. Inhibition of AKT has been shown to abolish the a

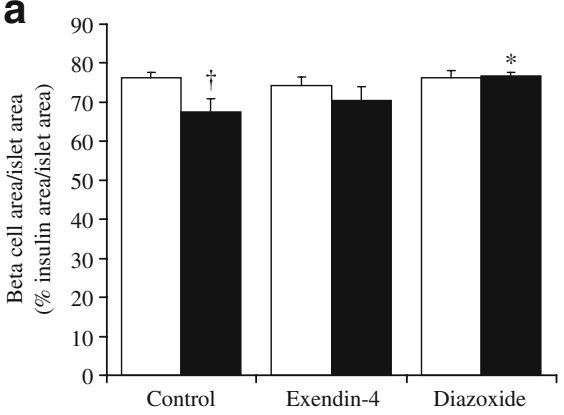

b

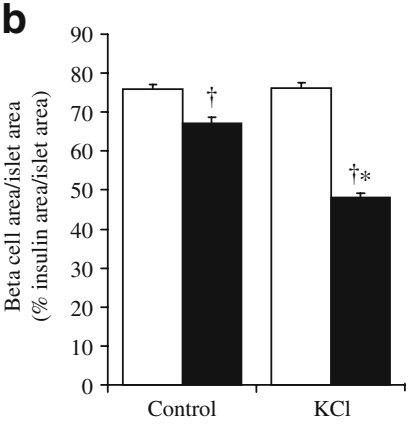

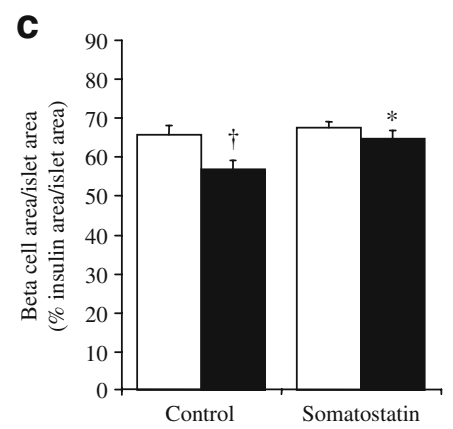

Fig. 5 a Beta cell area/islet area (\% insulin area/islet area) in nontransgenic (white bars) and human IAPP transgenic (black bars) islets cultured for $48 \mathrm{~h}$ in $16.7 \mathrm{mmol} / 1$ glucose with treatments as labelled. Treatments: no drug (control), exendin-4 (10 nmol/l), diazoxide
(250 $\mu \mathrm{mol} / \mathrm{l}), \mathrm{KCl}(10 \mathrm{mmol} / \mathrm{l})$, somatostatin $(100 \mathrm{nmol} / \mathrm{l})$. Values are mean $\pm \mathrm{SEM} ; n=6-8$ (non-transgenic), $n=8-9$ (human IAPP transgenic); ${ }^{*} p<0.05$ vs control, ${ }^{\dagger} p<0.05$ vs non-transgenic 
a

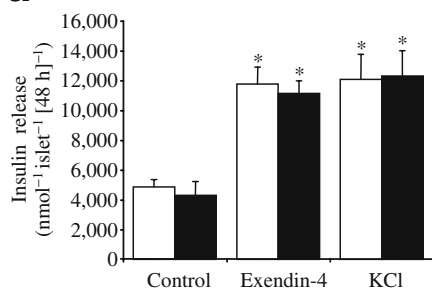

b

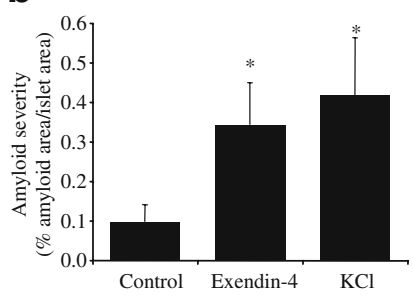

C

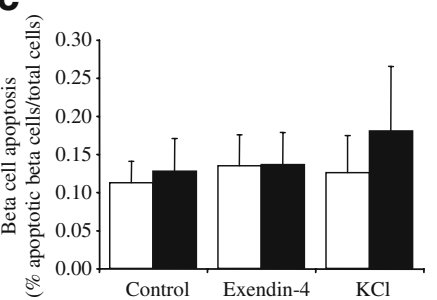

d

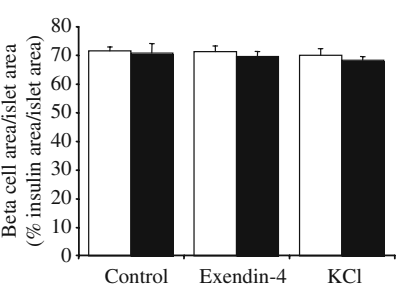

Fig. 6 a Insulin release $\left(\mathrm{nmol} 1^{-1}\right.$ islet $\left.^{-1}[48 \mathrm{~h}]^{-1}\right)$, (b) islet amyloid severity (\% amyloid area/islet area), (c) beta cell apoptosis (\% apoptotic beta cells/total cells) and (d) beta cell area/islet area (\% insulin area/islet area) in non-transgenic (white bars) and human
IAPP transgenic (black bars) islets cultured for $48 \mathrm{~h}$ in $11.1 \mathrm{mmol} /$ 1 glucose with treatments as labelled. Non-transgenic islets did not form amyloid. Treatments: no drug (control), exendin-4 (10 nmol/l), $\mathrm{KCl}(10 \mathrm{mmol} / \mathrm{l})$. Values are mean $\pm \mathrm{SEM} ; n=6 ;{ }^{*} p<0.05$ vs control ability of GLP-1 receptor agonist to protect against the deleterious effects of cytokines [34, 35], and gluco- and/or lipotoxicity $[34,36]$, indicating that activation of AKT is a major mechanism by which GLP-1 receptor agonists protect beta cells. On the other hand, GLP-1 receptor agonist protection from ER stress has been shown to occur via direct modulation of the ER stress pathway [37]. As we have previously shown that ER stress is not induced in human IAPP transgenic or non-transgenic islets cultured in $16.7 \mathrm{mmol} / \mathrm{l}$ glucose [38], we focused on the AKT pathway as the mechanism by which exendin-4 could protect against amyloid-associated apoptosis. We found no difference in AKT activation between human IAPP transgenic and nontransgenic islets, indicating that decreased AKT activation is not a mechanism by which amyloid that is formed from physiological amounts of endogenously produced human IAPP exerts its beta cell toxicity. However, exendin-4 treatment significantly increased AKT activation in human $I A P P$ transgenic and non-transgenic islets. Therefore it is feasible that the limiting effect of exendin- 4 on beta cell apoptosis occurred via increased AKT activation. Our

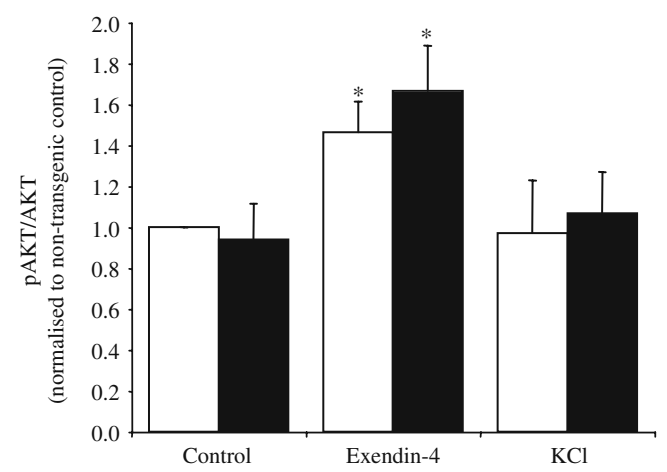

Fig. 7 pAKT levels normalised to total AKT in non-transgenic (white bars) and human IAPP transgenic (black bars) islets cultured for $48 \mathrm{~h}$ in $16.7 \mathrm{mmol} / 1$ glucose with treatments as labelled. Non-transgenic islets did not form amyloid. Treatments: no drug (control), exendin-4 $(10 \mathrm{nmol} / \mathrm{l}), \mathrm{KCl}(10 \mathrm{mmol} / \mathrm{l})$. Values are mean $\pm \mathrm{SEM} ; n=5 ; * p<0.05$ vs control observations are in keeping with a recent report that acute treatment of the INS-1 beta cell line with exogenously applied, supraphysiological concentrations of synthetic human IAPP induced apoptosis and growth inhibition, a toxic effect from which exendin-4 partially protected by increasing AKT activation [23].

We have shown that while exendin- 4 can decrease beta cell apoptosis in human IAPP transgenic islets, there was no effect in non-transgenic islets. As exendin- 4 is well documented to have anti-apoptotic effects in mouse islets $[19,39]$ and we also demonstrated that exendin-4 treatment resulted in increased AKT activation, this was somewhat surprising. However, the studies where a beneficial effect of exendin- 4 was shown were performed under stress conditions, in which apoptosis was elevated. We have previously shown that non-transgenic islets cultured for $48 \mathrm{~h}$ in $16.7 \mathrm{mmol} / 1$ glucose do not exhibit stress responses such as oxidative stress, ER stress or elevated beta cell apoptosis compared with non-transgenic islets cultured in $5.5 \mathrm{mmol} / \mathrm{l}$ glucose $[6,38]$. Thus, it is likely that exendin-4 treatment and/or elevated levels of phospho-AKT under these non-stress conditions does not decrease the low levels of basal beta cell apoptosis.

Interestingly, in this study exendin-4 did not increase beta cell proliferation or insulin mRNA levels or content. Beta cell proliferation has been shown to increase with exendin-4 treatment in many $[19,40]$, but not all, rodent studies $[40,41]$. Therefore the effects of exendin- 4 on proliferation may depend on many factors, including the diabetic milieu, the prevailing beta cell replication rate and the animal strain used. Additionally, to our knowledge, no studies have shown that exendin-4 increases proliferation in vitro in cultured islets. In fact one study has demonstrated that GLP-1 receptor activation increased proliferation in vivo, but did not affect proliferation when islets from the same mice were studied in vitro [40]. Thus it is possible that exendin-4 is unable to stimulate proliferation in vitro. Similarly, insulin mRNA and content have been shown to be increased with GLP-1 receptor activation in some 
studies [20, 42], but not others [43]. Thus, these effects of exendin-4 may also depend upon the diabetic milieu, animal strain or culture conditions used.

A limitation of using an in vitro culture system is that the effect of exendin- 4 on pancreatic progenitor cell proliferation cannot be assessed. Studies have shown that GLP-1 signalling promotes neogenesis thereby increasing beta cell mass $[22,44]$. Thus it is possible that in the setting of islet amyloidogenesis exendin- 4 may still promote neogenesis and thus contribute to improved beta cell mass and function in the long term. Therefore, further work is required using an in vivo model to assess the combined effect of amyloid and exendin- 4 on beta cell neogenesis. An in vivo model would also allow further examination of the long-term consequences of exendin- 4 treatment on amyloid deposition and its toxic effects.

We have shown that exendin- 4 treatment is beneficial to maintenance of beta cell area/islet area under amyloidogenic conditions as compared with $\mathrm{KCl}$ treatment. However, when compared with untreated human IAPP transgenic islets, exendin-4 did not seem to have a beneficial effect. This observation is comparable to findings from clinical studies which show a beneficial effect on glycaemic control during active treatment [15-17], but no persistent glucose-lowering benefit of treatment after withdrawal of the drug, consistent with a lack of clinically significant improvement of beta cell mass [45]. However, we have now shown that to correctly interpret the effects of exendin-4, a control that is appropriately matched for insulin release must be used. The possibility of a difference between GLP- receptor agonists and other insulin secretagogues such as sulfonylureas will need to be addressed in a long-term clinical study.

In summary, we have shown that human IAPP release is a critical determinant of amyloid formation in vitro and that increased human IAPP release with $\mathrm{KCl}$ results in increased amyloid formation, increased beta cell apoptosis and decreased beta cell area/islet area. However, exendin-4, probably via increased AKT activation, offsets the effect of increased amyloid formation on increased beta cell apoptosis or decreased beta cell area. Thus, from the clinical perspective, it is possible that treatment of type 2 diabetes with insulin secretagogues may result in increased amyloid formation and exacerbation of beta cell death, but that use of GLP-1 receptor agonists such as exendin-4 may offset some of these adverse effects and thus may be beneficial in terms of limiting loss of beta cell mass and progression of type 2 diabetes.

Acknowledgements We thank C. Braddock, B. Barrow, M. Cone, J. Willard, M. Watts, M. Peters, C. Forsyth and R. Bhatti for excellent technical support. This work was supported by the Department of Veterans Affairs and National Institutes of Health grants DK-075998 (to S. E. Kahn), DK-074404 (to R. L. Hull), DK-080945 (to S. Zraika), DK-007247 and DK-017047. K. Aston-Mourney was supported by an American Diabetes Association Mentor-Based
Fellowship and the University of Washington McAbee Fellowship. J. Udayasankar was supported by a Juvenile Diabetes Research Foundation Postdoctoral Fellowship.

Duality of interest The authors declare that there is no duality of interest associated with the manuscript.

\section{References}

1. Kahn SE, Zraika S, Utzschneider KM, Hull RL (2009) The beta cell lesion in type 2 diabetes: there has to be a primary functional abnormality. Diabetologia 52:1003-1012

2. Turner RC (1998) The U.K. prospective diabetes study. A review. Diabetes Care 21(Suppl 3):C35-C38

3. Clark A, Wells CA, Buley ID et al (1988) Islet amyloid, increased A-cells, reduced B cells and exocrine fibrosis: quantitative changes in the pancreas in type 2 diabetes. Diabetes Res 9:151-159

4. Hull RL, Andrikopoulos S, Verchere CB et al (2003) Increased dietary fat promotes islet amyloid formation and beta-cell secretory dysfunction in a transgenic mouse model of islet amyloid. Diabetes 52:372-379

5. Westermark P, Wilander E (1978) The influence of amyloid deposits on the islet volume in maturity onset diabetes mellitus. Diabetologia 15:417-421

6. Zraika S, Hull RL, Udayasankar J et al (2009) Oxidative stress is induced by islet amyloid formation and time-dependently mediates amyloid-induced beta cell apoptosis. Diabetologia 52:626-635

7. Zraika S, Hull RL, Udayasankar J et al (2007) Glucose- and timedependence of islet amyloid formation in vitro. Biochem Biophys Res Commun 354:234-239

8. Kahn SE, D'Alessio DA, Schwartz MW et al (1990) Evidence of cosecretion of islet amyloid polypeptide and insulin by beta-cells. Diabetes 39:634-638

9. Clark A, Saad MF, Nezzer Tet al (1990) Islet amyloid polypeptide in diabetic and non-diabetic Pima Indians. Diabetologia 33:285-289

10. Westermark G, Arora MB, Fox N et al (1995) Amyloid formation in response to beta cell stress occurs in vitro, but not in vivo, in islets of transgenic mice expressing human islet amyloid polypeptide. Mol Med 1:542-553

11. D'Alessio DA, Verchere CB, Kahn SE et al (1994) Pancreatic expression and secretion of human islet amyloid polypeptide in a transgenic mouse. Diabetes 43:1457-1461

12. Hull RL, Shen ZP, Watts MR et al (2005) Long-term treatment with rosiglitazone and metformin reduces the extent of, but does not prevent, islet amyloid deposition in mice expressing the gene for human islet amyloid polypeptide. Diabetes 54:2235-2244

13. MacArthur DL, de Koning EJ, Verbeek JS, Morris JF, Clark A (1999) Amyloid fibril formation is progressive and correlates with beta-cell secretion in transgenic mouse isolated islets. Diabetologia 42:1219-1227

14. D'Alessio DA, Vahl TP (2004) Glucagon-like peptide 1: evolution of an incretin into a treatment for diabetes. Am J Physiol Endocrinol Metab 286:E882-E890

15. DeFronzo RA, Ratner RE, Han J, Kim DD, Fineman MS, Baron AD (2005) Effects of exenatide (exendin-4) on glycemic control and weight over 30 weeks in metformin-treated patients with type 2 diabetes. Diabetes Care 28:1092-1100

16. Nauck MA, Ratner RE, Kapitza C, Berria R, Boldrin M, Balena R (2009) Treatment with the human once-weekly glucagon-like peptide-1 analog taspoglutide in combination with metformin improves glycemic control and lowers body weight in patients with type 2 diabetes inadequately controlled with metformin alone: a double-blind placebo-controlled study. Diabetes Care 32:1237-1243 
17. Zinman B, Gerich J, Buse JB et al (2009) Efficacy and safety of the human glucagon-like peptide-1 analog liraglutide in combination with metformin and thiazolidinedione in patients with type 2 diabetes (LEAD-4 Met+TZD). Diabetes Care 32:1224-1230

18. Farilla L, Bulotta A, Hirshberg B et al (2003) Glucagon-like peptide 1 inhibits cell apoptosis and improves glucose responsiveness of freshly isolated human islets. Endocrinology 144:5149-5158

19. Farilla L, Hui H, Bertolotto C et al (2002) Glucagon-like peptide-1 promotes islet cell growth and inhibits apoptosis in Zucker diabetic rats. Endocrinology 143:4397-4408

20. Kim JG, Baggio LL, Bridon DP et al (2003) Development and characterization of a glucagon-like peptide 1-albumin conjugate: the ability to activate the glucagon-like peptide 1 receptor in vivo. Diabetes 52:751-759

21. Rolin B, Larsen MO, Gotfredsen CF et al (2002) The long-acting GLP-1 derivative NN2211 ameliorates glycemia and increases beta-cell mass in diabetic mice. Am J Physiol Endocrinol Metab 283:E745-E752

22. Xu G, Stoffers DA, Habener JF, Bonner-Weir S (1999) Exendin-4 stimulates both beta-cell replication and neogenesis, resulting in increased beta-cell mass and improved glucose tolerance in diabetic rats. Diabetes 48:2270-2276

23. Fan R, Li X, Gu X, Chan JC, Xu G (2010) Exendin-4 protects pancreatic beta cells from human islet amyloid polypeptideinduced cell damage: potential involvement of AKT and mitochondria biogenesis. Diabetes Obes Metab 12:815-824

24. Khemtemourian L, Killian JA, Hoppener JW, Engel MF (2008) Recent insights in islet amyloid polypeptide-induced membrane disruption and its role in beta-cell death in type 2 diabetes mellitus. Exp Diab Res 2008:421287

25. Haataja L, Gurlo T, Huang CJ, Butler PC (2008) Islet amyloid in type 2 diabetes, and the toxic oligomer hypothesis. Endocr Rev 29:303-316

26. Westermark P, Engstrom U, Johnson KH, Westermark GT, Betsholtz C (1990) Islet amyloid polypeptide: pinpointing amino acid residues linked to amyloid fibril formation. Proc Natl Acad Sci USA 87:5036-5040

27. Verchere CB, D'Alessio DA, Palmiter RD et al (1996) Islet amyloid formation associated with hyperglycemia in transgenic mice with pancreatic beta cell expression of human islet amyloid polypeptide. Proc Natl Acad Sci USA 93:3492-3496

28. Udayasankar J, Kodama K, Hull RL et al (2009) Amyloid formation results in recurrence of hyperglycaemia following transplantation of human IAPP transgenic mouse islets. Diabetologia 52:145-153

29. Dunbar JC, Foa PP (1974) An inhibitory effect of tolbutamide and glibenclamide (glyburide) on the pancreatic islets of normal animals. Diabetologia 10:27-35

30. Rabuazzo AM, Buscema M, Vinci C et al (1992) Glyburide and tolbutamide induce desensitization of insulin release in rat pancreatic islets by different mechanisms. Endocrinology 131:1815-1820
31. Baggio LL, Kim JG, Drucker DJ (2004) Chronic exposure to GLP-1R agonists promotes homologous GLP-1 receptor desensitization in vitro but does not attenuate GLP-1R-dependent glucose homeostasis in vivo. Diabetes 53(Suppl 3):S205-S214

32. Emamaullee JA, Merani S, Toso C et al (2009) Porcine marginal mass islet autografts resist metabolic failure over time and are enhanced by early treatment with liraglutide. Endocrinology 150:2145-2152

33. Lavine JA, Attie AD (2010) Gastrointestinal hormones and the regulation of beta-cell mass. Ann NY Acad Sci 1212:41-58

34. Bregenholt S, Moldrup A, Blume $\mathrm{N}$ et al (2005) The long-acting glucagon-like peptide-1 analogue, liraglutide, inhibits beta-cell apoptosis in vitro. Biochem Biophys Res Commun 330:577-584

35. Li L, El-Kholy W, Rhodes CJ, Brubaker PL (2005) Glucagon-like peptide-1 protects beta cells from cytokine-induced apoptosis and necrosis: role of protein kinase B. Diabetologia 48:1339-1349

36. Buteau J, El-Assaad W, Rhodes CJ, Rosenberg L, Joly E, Prentki M (2004) Glucagon-like peptide-1 prevents beta cell glucolipotoxicity. Diabetologia 47:806-815

37. Cunha DA, Ladriere L, Ortis F et al (2009) Glucagon-like peptide-1 agonists protect pancreatic beta-cells from lipotoxic endoplasmic reticulum stress through upregulation of BiP and JunB. Diabetes 58:2851-2862

38. Hull RL, Zraika S, Udayasankar J, Aston-Mourney K, Subramanian SL, Kahn SE (2009) Amyloid formation in human IAPP transgenic mouse islets and pancreas, and human pancreas, is not associated with endoplasmic reticulum stress. Diabetologia 52:1102-1111

39. Li Y, Hansotia T, Yusta B, Ris F, Halban PA, Drucker DJ (2003) Glucagon-like peptide-1 receptor signaling modulates beta cell apoptosis. J Biol Chem 278:471-478

40. Edvell A, Lindstrom P (1999) Initiation of increased pancreatic islet growth in young normoglycemic mice (Umea $+/$ ?). Endocrinology 140:778-783

41. Sherry NA, Chen W, Kushner JA et al (2007) Exendin-4 improves reversal of diabetes in NOD mice treated with anti-CD3 monoclonal antibody by enhancing recovery of beta-cells. Endocrinology 148:5136-5144

42. Wang Y, Perfetti R, Greig NH et al (1997) Glucagon-like peptide-1 can reverse the age-related decline in glucose tolerance in rats. J Clin Investig 99:2883-2889

43. Kim H, Haluzik M, Asghar Z et al (2003) Peroxisome proliferator-activated receptor-alpha agonist treatment in a transgenic model of type 2 diabetes reverses the lipotoxic state and improves glucose homeostasis. Diabetes 52:1770-1778

44. Hui H, Wright C, Perfetti R (2001) Glucagon-like peptide 1 induces differentiation of islet duodenal homeobox-1-positive pancreatic ductal cells into insulin-secreting cells. Diabetes 50:785-796

45. Bunck MC, Diamant M, Corner A et al (2009) One-year treatment with exenatide improves beta-cell function, compared with insulin glargine, in metformin-treated type 2 diabetic patients: a randomized, controlled trial. Diabetes Care 32:762-768 